\title{
Proteomic signatures of the oyster metabolic response to herpesvirus OsHV-1 $\mu$ Var infection
}

\author{
Charlotte Corporeau ${ }^{\mathrm{a}, *}$, David Tamayo ${ }^{\mathrm{a}, \mathrm{b}}$, Fabrice Pernet $^{\mathrm{a}}{\text {, Claudie } \text { Quéré }^{\mathrm{a}} \text {, Stéphanie Madec }}^{\mathrm{c}}$
}

\begin{abstract}
a Ifremer, Laboratoire des sciences de l'Environnement Marin (UMR 6539, LEMAR), 29280 Plouzané, France
b Departamento GAFFA (Animal Physiology), Facultad de Ciencia y Tecnología, Universidad del País Vasco/Euskal Herriko Unibertsitatea, Apartado 644, 48080 Bilbao, Spain

${ }^{c}$ Laboratoire Universitaire de Biodiversité et Ecologie Microbienne (EA3882), IFR148 ScInBioS, Université Européenne de Bretagne, ESMISAB, Technopôle de Brest Iroise, 29280 Plouzané, France
\end{abstract}

\author{
*: Corresponding author : Charlotte Corporeau, tel.: + 33298224764 ; fax: + 33298224653 ; email address : \\ charlotte.corporeau@ifremer.fr
}

\begin{abstract}
:
Pacific oyster Crassostrea gigas were inoculated with OsHV-1 at low load (control) or high load (challenged) to better understand the pathogenesis of ostreid herpesvirus 1 (OsHV-1 $\mu$ Var) and to determine which metabolic pathways might be affected during infection. Animals were sampled for proteomic analysis two days post-injection, at the same time as OsHV-1 initiated an intense replication phase in challenged oysters. Twenty-five abundant protein spots that showed a marked change in accumulated levels were identified using a two-dimensional electrophoresis (2-DE) proteomic approach. Overall, these proteins are involved in cytoskeleton organization, protein turnover, induction of stress signals, signalling pathways and energy metabolism. Challenged oysters exhibited an increased glycolysis and VDAC accumulation, which reflect a "Warburg effect" as initially reported in cancer cells and more recently in shrimp infected with virus. The results presented here should be useful for identifying potential biomarkers of disease resistance and developing antiviral measures.
\end{abstract}

\section{Biological significance}

This study is the first 2-DE proteomic analysis dedicated to the pathogenesis of ostreid herpesvirus 1 (OsHV-1 $\mu$ Var) in oyster Crassostrea gigas, the most important bivalve produced in the world. OsHV-1 has affected oysters every year since 2008. All the proteins identified in this paper are key targets involved in OsHV-1 infection processes. We presented evidence that the metabolic changes during infection in oyster somehow resemble the Warburg effect occurring in cancer cells. This work constitutes a real advance in the comprehension of the host metabolic pathways affected during OsHV-1 disease. Overall, this work contributes to a better understanding of disease mortalities in aquatic ecosystems which could guide management actions to mitigate their impacts. 


\section{Graphical abstract}

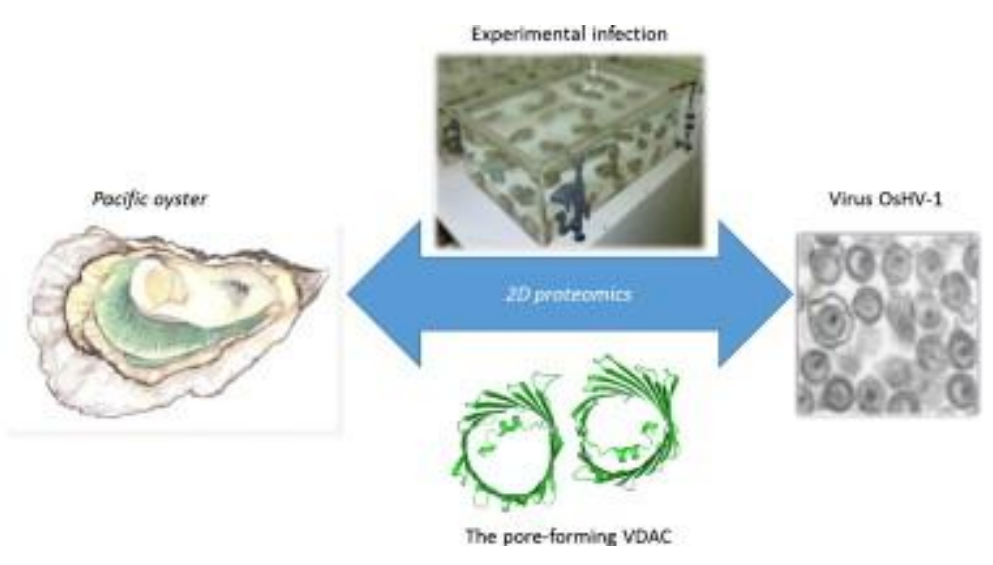

\section{Highlights}

Pacific oysters were experimentally infected with the ostreid herpes virus OsHV-1. Oysters were chosen based on their OsHV-1 DNA concentration for proteomic analysis. - Two-dimensional proteomics identified signatures of the oyster metabolic response to herpesvirus OsHV-1 $\mu$ Var infection. Challenged oysters exhibited an increased glycolysis and VDAC accumulation, which reflect a "Warburg effect."

\section{Abbreviations}

- OsHV-1 $\mu$ Var, ostreid herpes virus 1 microvariant ;

- MS, mass spectrometry ;

- HPLC, high performance liquid chromatography ;

- 2-DE, two-dimensional electrophoresis

Keywords : Marine bivalves ; Crassostrea gigas ; Herpesvirus ; Metabolism ; Warburg 


\section{INTRODUCTION}

Since 2008, juvenile Crassostrea gigas have suffered mass mortalities in all rearing sites along the French coast when seawater temperature exceeds $16^{\circ} \mathrm{C}$ [1-5]. Juvenile oysters $(<1$ yr) are decimated at levels ranging from 40 to $100 \%$, depending on locations and batches, whereas older animals are generally much less affected [2, 6, 7]. Although C. gigas mortalities have been mostly reported in France during this period, there have also been several cases in UK, Australia and New Zealand [1, 8-12].

Results of diagnostic tests show that recent mortality events are associated with the detection of a particular genotype of the ostreid herpesvirus 1 (OsHV-1) named $\mu$ Var [10, 13]. Notably, by 2009 the OsHV-1 $\mu$ Var had fully replaced the reference OsHV-1 genotype in seed, presenting mortality at all French oyster production sites [14]. The role of OsHV-1 in oyster mortalities has been proven experimentally by intramuscular injections of viral suspensions prepared from naturally infected oysters [15] or by cohabitation between healthy and infected oysters $[4,16]$.

To understand the pathogenesis of any disease, knowledge of the interactions between virus and host is critical [17]. Virus-host interactions generally result in immune responses against the invader, and in changes in the expression levels of host genes that favor virus replication. However, few studies have been performed concerning the physiological response of oysters to herpesvirus. Most studies have investigated interactions of OsHV-1 and C. gigas at the transcriptional level using expressed sequence tags, RT-PCR, microarray chips, suppression subtractive hybridization or differential hybridization [18-25]. Gene expression profiling was compared between oysters selected for resistance to summer mortalities (a phenomenon in which OsHV-1 reference was presumably involved) and susceptible animals [18-21,24], oysters injected with OsHV-1 $\mu$ Var and control animals [22, 23], or field oysters exposed to OsHV-1 $\mu$ Var and oysters held in sanctuary areas [22, 25]. Therefore, many of these 
experimental studies were not designed for investigating the sole effects of OsHV-1 as other factors confound comparisons between studies or treatment groups. Also, despite the fact that these studies provide a first basis on the role of innate immunity, immunomodulation, stress response and reproduction in oyster infections [19-25], little is known about the metabolic events associated with OsHV-1 infection in oysters.

In the present paper we have used for the first time a two-dimensional electrophoresis (2-DE) proteomic approach to identify metabolic pathways involved in OsHV-1 infection to provide a better understanding of virus-host interactions. We analysed the proteomes of oysters injected with OsHV-1 at different concentrations under controlled conditions. The proteins that were markedly up- or down- accumulated during OsHV-1 infection were identified using tandem mass spectrometry.

\section{MATERIALS AND METHODS}

\section{Oysters}

Triploid 8 month-old Crassostrea gigas oysters were collected in March 2009 in a farming area in Aber Benoit (northern Brittany, France, $48^{\circ} 48^{\prime} 24.5^{\prime \prime} \mathrm{N}, 3^{\circ} 0^{\prime} 22.8^{\prime \prime} \mathrm{W}$ ) where no mortality had been recorded. Animals were then transferred to the Ifremer marine station

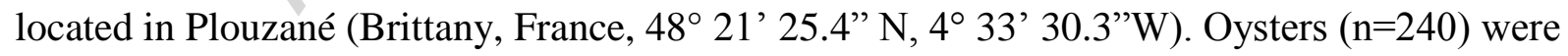
maintained in a 5001 flow-through tank for 2 weeks, with seawater at $20^{\circ} \mathrm{C}$ and enriched with a phytoplankton mixture. Seawater was treated with UV radiation and filtered at $1 \mu \mathrm{m}$. Animals did not present any mortality or other symptom of disease prior to the experimental infection.

\section{Experimental design}

The experimental infection protocol has been described by Normand et al. [22]. Briefly, the oysters were anesthetized with $\mathrm{MgCl} 2$ (3/5 fresh water, $2 / 5$ seawater with $50 \mathrm{~g} / \mathrm{L} \mathrm{MgCl}_{2}$ ) for 5 
hours [26] and injected in the adductor muscle [15] with $100 \mu$ inoculate that was considered either virulent (high load) or weakly virulent (low load), corresponding to $2.10^{9}$ or $4.10^{6}$ copies of viral genome injected, respectively (quantified by real-time PCR).

Inoculates were prepared by grinding 20 grams of fresh oyster flesh. The flesh was then diluted 40 fold in sterile seawater, and filtered three times on $0.1 \mu \mathrm{m}$ sterile membrane filters to remove bacteria before being injected into experimental oysters [15]. For the high-load inoculate, tissue originated from three live oysters collected from a broodstock where mortalities were occurring, whereas for the low-load inoculate, the tissue originated from animals collected in an area where no mortality had been reported (presumably healthy). A sub-sample of $1 \mathrm{ml}$ from each inoculum was taken and frozen into liquid nitrogen for subsequent titration of genomic copies of OsHV-1.

After injection, oysters from challenged (high load) and control (low load) groups were divided into $2 \times 3$ batches of 40 injected oysters [22]. Each batch was randomly placed in a 20-L tank filled with $1-\mu \mathrm{m}$ filtered seawater at $20^{\circ} \mathrm{C}$ with aeration, food supply and no seawater renewal.

At days 2 and 6 post-injection (dpi), 10 oysters were collected in each tank ( $\mathrm{n}=30$ samples per day and injection condition), opened and the entire flesh of each animal immediately frozen in liquid nitrogen for subsequent OsHV-1 analysis. At 2 dpi, before the onset of mortality in the high load treatment, challenged and control oysters were collected for proteomic analysis ( $\mathrm{n}=5$ specimen for each condition). Challenged oysters used for proteomic analysis were selected from tanks 1 and 2 whereas control animals were from tanks 4 and 5 (Table 1). Animals were selected based on their level of OsHV-1 DNA (the highest for challenged animals and the lowest for control ones). Mortality was monitored daily by counting dead and live individuals. Dead oysters were removed from the tanks.

\section{Titration of OsHV-1 DNA copy number}


Total DNA was extracted from inocula and oyster tissues as described for real-time PCR assay analyses [15]. The detection and quantification of OsHV-1 DNA copy number was carried out in triplicates using real-time PCR [27] with specific primers that amplified both OsHV-1 reference and $\mu$ Var types. Briefly, DNA extraction was carried out using a commercial DNA tissue kit (QIAGEN - QIAamp tissue mini kit). Nucleic acids quantification was measured immediately using a spectrophotometer and final concentration of DNA in samples adjusted to 3ng/ $\mu \mathrm{L}$. OsHV-1 DNA amplification was performed using $\mathrm{C}_{9}$ and $\mathrm{C}_{10}$ primers on MyIQ2 Thermocycler (Biorad) using the following thermal profile: 1 cycle of preincubation $\left(95^{\circ} \mathrm{C}, 10 \mathrm{~min}.\right), 40$ cycles of amplification/detection $\left(95^{\circ} \mathrm{C}, 30 \mathrm{~s} . ; 60^{\circ} \mathrm{C}\right.$, $1 \mathrm{~min} . ; 72^{\circ} \mathrm{C}, 1 \mathrm{~min}$.), and a final sequence of melting temperature curve analysis $\left(95^{\circ} \mathrm{C}, 1 \mathrm{~min}\right.$.; $60^{\circ} \mathrm{C}, 30 \mathrm{~s}$; $95^{\circ} \mathrm{C}, 30 \mathrm{~s}$.). Absolute quantification of OsHV-1 DNA copies was carried out by comparing the $\mathrm{Ct}$ values obtained for tested samples with a standard curve based on a ten-fold dilution of a stock solution of OsHV-1 genomic DNA $\left(5 \times 10^{6}\right.$ copies $\left./ \mu \mathrm{L}\right)$ extracted from purified virus particles [28]. The results were expressed as virus DNA copy numbers per ng total DNA. Standardization of OsHV-1 genomic DNA quantity was reached using DNA concentrations measured using an ND-1000 spectrophotometer (Nanodrop Technologies) at $260 \mathrm{~nm}$ with the conversion factor of $1 \mathrm{OD}=50 \mu \mathrm{g} / \mathrm{mL}$ DNA.

\section{Total protein extraction from oyster tissues}

To solubilize proteins, $5 \mathrm{ml}$ lysis buffer $(150 \mathrm{mM} \mathrm{NaCl}, 10 \mathrm{mM}$ Tris, $1 \mathrm{mM}$ EDTA, $1 \mathrm{mM}$ EGTA, $1 \%$ Triton X-100, $0.5 \%$ Igepal, 1 tablet of complete EDTA free protease inhibitor cocktail in $25 \mathrm{ml}$ of buffer, phosphatase inhibitor cocktail III) were added to $1 \mathrm{~g}$ of powdered tissue. Total proteins were then extracted as described elsewhere [29, 30]. For each lysate, the total protein content was quantified using a $\mathrm{D}_{\mathrm{C}}$ protein assay (Bio-Rad, Hercules, CA, USA) with 96-well micro-plates $\left(\mathrm{Nunc}^{\mathrm{TM}}\right.$ ) in a micro-plate reader (Bio-Tek® SynergyTM HT) and KC4 v3 software to compare results with a calibration curve of standard proteins (Bovine 
Serum Albumin) provided with the $\mathrm{D}_{\mathrm{C}}$ protein assay kit.

\section{Two-dimensional electrophoresis}

For each sample, an equal amount $(500 \mu \mathrm{g})$ of total protein lysate was precipitated and desalted [31] to limit the presence of non-protein impurities such as salts, buffers, or remnant lipids in the samples before IsoElectroFocusing (IEF). Precipitation and desalting were performed by adding 2 volumes of $20 \%$ TCA on ice for $20 \mathrm{~min}$. The samples were then centrifuged at $12,000 \mathrm{~g}$ for $15 \mathrm{~min}$ and the pellet washed 5 times with $80 \%$ acetone in $0.05 \mathrm{M}$ Tris- $\mathrm{HCl} \mathrm{pH}$ 8. Proteins were resuspended in a rehydrating solution (DeStreak, GE Healthcare) containing $1 \%$ Immobilized $\mathrm{pH}$ Gradient ampholytes (IPG) and placed at room temperature for $1 \mathrm{~h}$ before IEF. The IEF dimension was conducted on a Bio-Rad Protean IEF Cell system $^{\mathrm{TM}}$ (Bio-Rad, Hercules, CA, USA). Total proteins were loaded onto each strip (Immobiline DryStrip pH 3-10, $11 \mathrm{~cm}$, GE Healthcare), and passive rehydration allowed at room temperature overnight using mineral oil to prevent sample evaporation. The IEF was carried out at $20^{\circ} \mathrm{C}$ in four steps: a calibration step at $100 \mathrm{~V}$ constant voltage for $3 \mathrm{~h}$, an active hydration step at $300 \mathrm{~V}$ constant voltage for $1 \mathrm{~h}$, a continuous increase in voltage up to $8000 \mathrm{~V}$ over $8 \mathrm{~h}$ to start migration, and a migration step at $8000 \mathrm{~V}$ constant voltage for 11 hours. Before the second dimension, the IPG strip was rehydrated for $15 \mathrm{~min}$ in a solution for saturation containing $6 \mathrm{M}$ urea, $2 \% \mathrm{SDS}, 30 \%$ glycerol and $1 \%$ DTT in $0.05 \mathrm{M}$ Tris- $\mathrm{HCl} \mathrm{pH}$ 8.8. The strip was then further equilibrated for $15 \mathrm{~min}$ in a similar buffer, in which DTT was replaced with $2.5 \%$ iodoacetamide to alkylate the proteins. For the second dimension of the 2-D electrophoresis, 8-16 \% gradient SDS-PAGE precast gels (Bio-Rad, Hercules, CA, USA) were used, run on a Criterion system (Bio-Rad, Hercules, CA, USA). The gels were loaded with broad range SDS-PAGE molecular weight markers. Migration was realized at $200 \mathrm{~V}$ constant voltage for $1 \mathrm{~h}$. After 2-DE, protein spots were stained by Coomassie blue coloration (PlusOne Coomassie Tablets, PhastGel Blue R-350, GE Healthcare) and washed in $7 \%$ acetic 
acid, $30 \%$ methanol solution. For image analysis, 16-bit level images of the gels were captured in tagged image file format (TIFF) and analysed using Progenesis ${ }^{\mathrm{TM}}$ SameSpots v1.5 software (Nonlinear Dynamics, Newcastle upon Tyne, UK). A composite image of the 10 gels (one for each individual) was generated, spots were detected automatically and all spot volumes were normalized using built-in algorithms. After automatic spot detection, spot boundaries were manually edited and artefacts on the images removed. Normalized spot intensities were obtained for each spot on the images. A comparison was made between the spots on the two groups of 5 gels (high-load versus low-load).

\section{In-gel digestion for mass spectrometry}

Twenty-five Coomassie blue-stained spots of interest were excised from the SDS-PAGE and processed for trypsin digestion. Excised spots were washed twice with milliQ water and destained for $15 \mathrm{~min}$ in $100 \mathrm{mM} \mathrm{NH}_{4} \mathrm{HCO}_{3}$ and $50 \%$ acetonitrile $(\mathrm{ACN})$, then dehydrated in $100 \% \mathrm{ACN}$. They were re-hydrated in $100 \mathrm{mM} \mathrm{NH}_{4} \mathrm{HCO}_{3}$ and again dehydrated in $100 \%$ ACN. Excised spots were air-dried and in-gel digestion was performed overnight at $37{ }^{\circ} \mathrm{C}$ with modified trypsin (Promega, Charbonnières-les-Bains, France) at $12.5 \mathrm{ng} / \mu \mathrm{L}$ in $70 \mu \mathrm{L}$ of $50 \mathrm{mM} \mathrm{NH}_{4} \mathrm{HCO}_{3}$. The resulting tryptic peptides were extracted from the gel spots by sequential incubation in ACN / water / formic acid, 70:30:0.1 (v/v/v), then $100 \% \mathrm{ACN}$ and, finally, ACN / water / formic acid, 70:30:0.1 (v/v/v). The tryptic digests were then concentrated by vacuum centrifugation to reach a final volume of $30 \mu \mathrm{L}$.

\section{Nano LC-MS/MS analysis}

LC-MS/MS analyses were performed on a nano-HPLC system (Ultimate 3000, Dionex, Jouyen-Josas, France) coupled on-line with an Esquire HCT Ultra PTM Discovery mass spectrometer (Bruker Daltonics, Bremen, Germany) equipped with a nanoflow electrospray ionization source and an ion trap analyzer. Tryptic digests were concentrated by injecting 22 $\mu \mathrm{L}$ volumes into a Dionex C18 PepMap300 trapping reverse phase pre-column (5 $\mu \mathrm{m}, 300 \AA$ 
/ $5 \mathrm{~mm}$ x 300 $\mu \mathrm{m}$ inner diameter). Peptides were then passed onto a Dionex C18 PepMap100 reverse phase nano-column ( $3 \mu \mathrm{m}, 100 \AA$ / $150 \mu \mathrm{m}$ x $75 \mu \mathrm{m}$ inner diameter) and eluted with a gradient of $2 \%$ to $90 \% \mathrm{ACN}$ in $0.05 \%$ formic acid for $52 \mathrm{~min}$ at a flow rate of $250 \mathrm{~nL} / \mathrm{min}$. The mass spectrometer was operated in positive ionization mode with an analytical scan range of $\mathrm{m} / \mathrm{z}$ 150-2500 Th. Ion accumulation time was automatically set with an ion charge control (ICC) target of 90000 to avoid space charge effects. EsquireControl ${ }^{\mathrm{TM}}$ software (Bruker Daltonics) automatically alternated MS and MS/MS acquisitions in an exclusion dynamic mode (the seven most intense ions were selected and excluded from further selection for a duration of $0.25 \mathrm{~min}$ ). MS/MS data were acquired using a $4 \mathrm{~m} / \mathrm{z}$ unit ion isolation window and a $1.2 \mathrm{~V}$ fragmentation amplitude.

\section{Database searches}

MS/MS data files were used to query a protein database translated from the oyster genome [32]. Search parameters were as follow: one missed cleavage allowed, carbamidomethylation of cysteins set as fixed modification, methionine oxidation set as variable modification, 0.25 Da precursor tolerance and 0.5 Da fragment tolerance. Peptide identifications were accepted if the individual ion Mascot scores were above the identity threshold (an ion score $\mathrm{f}-10 \times \log (p)$ where $p$ is the probability that the observed match is a random event). In case of ambiguous assignments (fit with more than one peptide), peptides were accepted based on the peptide score, meaning that the peptide sequence with the highest score was accepted and it did not matter if the protein was contained in the list. The matching of identified peptides to proteins was performed with the ProteinExtractor algorithm [33], so that every protein reported was identified by at least one peptide with a significant ion Mascot score (above the identity threshold), that could not be mapped to a higher-ranking protein already in the result list. This means that the protein lists provided contain only those proteins and protein variants that could be distinguished directly by MS/MS. For every protein reported in the identification 
list, a combined protein score (metascore) was calculated from the peptide scores using the ProteinExtractor algorithm. The calculated peptide mass and pI of the translated ESTs were evaluated on the UNIPROT website (www.uniprot.org). The data have been deposited to the ProteomeXchange with identifier PXD000905.

\section{Statistical analysis}

Two-way nested ANOVA was conducted to determine differences in the quantity of herpesvirus OsHV-1 DNA detected in oyster tissues, as a function of injection load of OsHV1 (high vs. low), day post injection ( 2 vs. 6 dpi) and the interaction between factors. The term 'tank (OsHV-1 load)' was added in the ANOVA to investigate variations in the quantity of herpesvirus OsHV-1 DNA detected in oyster tissues among tanks within injection load. Then, one-way nested ANOVAs were conducted separately at 2 dpi and at 6 dpi to determine differences in the quantity of herpesvirus OsHV-1 DNA detected in oyster tissues as a function of injection load of OsHV-1 (Fig. 1, n=10 samples for each tank). Finally, one-way ANOVA was conducted to determine differences in the quantity of herpesvirus OsHV-1 DNA detected in oyster tissues sampled for proteomic analysis as a function of injection load of OsHV-1 ( $\mathrm{n}=5$ samples for each condition). Where differences were detected, least-squared means multiple comparison tests were used to determine which means were significantly different. Residuals were screened for normality using the expected normal probability plot and further tested using the Shapiro-Wilk test. Data on the quantity of herpesvirus OsHV-1 DNA were $\log (x+1)$ transformed to obtain normality of residuals and homogeneity of variances (SAS 9.3, SAS Institute).

Differences in spot (protein) abundance were statistically evaluated after normalisation ( $\mathrm{p}<$ 0.05), using the Progenesis Stats tool from the Progenesis SameSpots@ software package (Prodigy (C). 


\section{RESULTS AND DISCUSSION}

\section{Infection and mortality}

Oysters were injected with high load (challenged) or low load (control) inoculum of OsHV-1 $\mu$ Var, and live animals were sampled 2 days and 6 days post-injection (dpi) for quantification of OsHV-1 DNA in whole tissues. Inoculum and time interacted in their effects on quantity of OsHV-1 DNA detected in oyster tissues (ANOVA, $\mathrm{p}=0.0037$ ). At 2 dpi, quantity of OsHV-1 DNA in challenged oysters was 10000 times higher than in that of control oysters which remained low ( $<100 \mathrm{cp} \mathrm{ng}{ }^{-1}$ DNA, p<0.0001, Fig. 1). At 6 dpi, quantity of OsHV-1 DNA in control oysters increased up until reaching $1.09 \times 10^{5} \mathrm{cp} \mathrm{ng}^{-1}$ DNA, which remained 1.7 times lower than in challenged oysters $\left(1.87 \times 10^{5} \mathrm{cp} \mathrm{ng}^{-1} \mathrm{DNA}, \mathrm{p}=0.008\right)$. Therefore, our results suggest that the level and the kinetics of viral infection in challenged oysters were markedly higher than those recorded in control animals. These differences between treatments were reflected in oyster mortality. For instance, mortality started at 3 dpi in challenged oysters and nine individuals out of 60 died at $6 \mathrm{dpi}$, whereas for control oysters, only one oyster out of 60 died after 6 days.

Therefore, in challenged oysters, there was an interval of 2 days between injection and the outbreak of mortality, which agrees well with a previous study [16]. This time interval may reflect the incubation period required for the virus to initiate an intense replication phase leading to irreversible cell damage and oyster mortality [16, 34].

In our study, mortality was rather low ( $\sim 15 \%$ at 6 dpi in challenged oysters) compared to $\sim 80 \%$ at 4 dpi in Schikorsky et al. [16]. In our study, oysters were kept in a flow through system where seawater was renewed every $2 \mathrm{~h}$, whereas in Schikorsky et al. [16], oysters were kept in a closed system without seawater change. This result illustrates that disease mortality risk of susceptible oysters decreases with water renewal, reflecting dilution effects of viral particles in seawater [35]. 


\section{Proteomic signatures of viral infection}

We analysed 10 proteomes ( 5 challenged vs. 5 control oysters, $\mathrm{N}=2$ technical replicates for each analysis) obtained from individuals that exhibited contrasted infection status, as measured by their OsHV-1 DNA level (Table 1). Figures 2A and B shows the representative gel images of whole flesh oyster proteome at 2 dpi injected with high and low load inoculum, respectively.

Analysis of 2-DE pattern revealed that 25 spots (Fig. 3) showed significant differences in response to the load of inoculum injected. These 25 spots were excised from gels, subsequently digested with trypsin and were all successfully identified using nano-liquid chromatography coupled with tandem mass spectrometry. Tables 2 and 3 show the list of the proteins that are down- and up-accumulated in infected oysters injected with high-load OsHV-1 inoculum at 2 dpi. Perfect matches were obtained between the apparent molecular weight of proteins in the 2D-gels and the calculated molecular weight (Tables 2 and 3) extracted from the genome annotation [32]. The results of mass spectrometry analysis are given in supplementary tables (Table S2 and S3). Based on the nature of the proteins identified in this work, we characterised key metabolic processes regulated during OsHV-1 infection in Crassostrea gigas.

\section{Cytoskeleton disorganization}

Challenged oysters showed lower amount of Annexin and Adenylyl cyclase-associated protein (CAP; spot \#1), Dynein (spot \#3), Actin (spot \#4), $\alpha$-actinin (spot \#8), and Actin-2 and Debrin (spot \#9) compared to control animals, suggesting that cytoskeleton remodeling capacity was altered by OsHV-1. Indeed, regulation of actin and microtubule cytoskeleton architecture and dynamics is important for cell shape and motility [36-38], and is crucial in defining the life cycle of viruses [39-41], particularly for herpesvirus [42]. More particularly, 
a decreased in CAP expression is linked with the accumulation of filamentous F-actin in relation to G-actin, which implies a less dynamic but more stable actin filaments [43]. Overall, our results highlighted the key role of F-actin in the OsHV-1 life cycle, as already suggested by the over-expression of the talin2 gene in C. gigas infection in the field [25]. In fact, the cytoskeleton is modified during infection with viruses because it is used as a "highway" for virus trafficking within the cell $[40,44,45]$. Another transcriptomic study in $C$. gigas infected with OsHV-1 suggest that reduced actin dynamics might be responsible for a decrease in adhesion and engulfing capabilities in haemocyte [23].

Our results also show complex regulation of the intracellular trafficking between membranous organelles during OsHV-1 infection in the oyster, particularly between the endoplasmic reticulum and Golgi apparatus. Indeed, the Ras related protein RAB2 (spot \# 24) and the selenium binding protein (SBP1; spot \#20) were over-accumulated in challenged oysters, which indicate that intracellular trafficking to the Golgi compartment increased with OsHV-1 infection. Indeed, RAB is essential for transport from the endoplasmic reticulum to Golgi complex [46] and is necessary for viral movements within the cell $[39,40]$, specifically in herpes viral infections [47]. Moreover, SBP1 over-accumulation leads to an increase in the late (docking and fusion) intra-Golgi transport [48]. In fact, in vertebrates, herpesviruses exploit several host compartments for envelopment [49-51]. Herpesvirus nucleocapsids assemble in the nuclei of infected cells and acquire an envelope by budding through the inner nuclear membrane. After budding through the inner nuclear membrane, the enveloped virions are infectious but final envelopment occurs by budding into a cytoplasmic compartment [52]. The virus undergoes de-envelopment and re-envelopment steps during virus egress and its final envelopment is observed in the late Golgi compartment [52]. Indeed, the enveloped proteins of alphaherpesvirus accumulate in the Golgi compartment or in Golgi-derived vesicles [50]. 
Coatomer subunit zeta-1 (spot \#6), a protein involved in vesicles trafficking in the retrograde transport of luminal and membrane proteins from the trans-Golgi network (TGN) back to the endoplasmic reticulum [53], was down-accumulated in challenged oysters. Similarly, expression of Vsp53, which belongs to the retrograde transport from the Golgi, decreased at the mRNA level in oysters infected in the field [25]. The retention of herpesvirus in the endoplasmic reticulum is known to prevent the maturation of virion envelopes, while the redirection of viral particles to the endoplasmic reticulum lead to decreased infectivity of mature virions [50]. Taken together, our results revealed that increased intracellular transport to Golgi and reduced retrograde transport from Golgi might be involved in the maturation of OsHV-1 infectious particles in infected oyster.

\section{Dysregulation of protein turnover}

The Ubiquitin fusion degradation protein (UFD; spot \#2) was down-accumulated in challenged oysters compared to control animals, which suggest that ubiquitination was altered during OsHV-1 infection in C. gigas. UFD is directly involved in cytosolic protein degradation by ubiquitination and proteasome machineries [54]. In mice, modulation of ubiquitination is required for the efficient initiation of lytic cycle gene expression and the reactivation of latent virus [55]. The herpesvirus causing the white spot syndrome (WSSV) in the shrimp Penaeus japonicus modulates gene expression of proteins involved in ubiquitination, and may induce the degradation of cytokine signaling molecules responsible for the host immunomodulation [56]. In C. gigas, genes involved in ubiquitination are downregulated in OsHV-1 infected spat, and are likely involved in the early response to the pathogen [25].

Cyclophilin C (CyC; spot \#16) and elongation factor $1 \alpha(\mathrm{EF} 1 \alpha$; spot \#21) are involved in production of OsHV-1 proteins and were over-accumulated in challenged oysters. Indeed, viruses regulate cyclophilins that play a role in protein folding [57] to ensure an efficient 
production of virus polymerase [58]. EF1 $\alpha$ delivers tRNA to the elongating ribosome [59] and herpesvirus regulates the EF1 complex for accelerating or inducing the activity of translational machinery.

\section{Induction of stress signals}

Catalase (spot \#1) and Glutathione-S-transferases A (spot \#11 and 15) were downaccumulated whereas Extracellular Superoxide dismutase (Ec-SOD; spot \#25) was overaccumulated in challenged oysters. Altogether, this indicates that ROS balance was modulated during infection with OsHV-1. Previous genome-wide expression profiling study of gonad tissue from resistant and susceptible oysters highlighted antioxidant defense as constitutive pathways that operate differentially between these two lines during the critical period preceding a summer mortality outbreak in which OsHV-1 was presumably involved $[19,21]$. Moreover, we showed that Calponin-2 (spot \#16, 17, 22, 24) was over-accumulated in challenged animals, which likely reflects an increase in cellular levels of ROS in infected oysters linked to a lower actin dynamics [60].

Dihydropteridine reductase (DHPR; spot \#12) was down-accumulated in challenged oysters. In humans, a diminished expression of DHPR is a potent biomarker for hypertensive vessels [61]. Our result could indicate that endothelial cells are affected by the stress induced by OsHV-1 infection.

Three aldehyde dehydrogenases (ALDH; spot \#20) were over-accumulated in challenged oysters. This result might reflect an increased ability of oysters to clear toxic aldehyde substances during infection with OsHV-1. Aldehydes are strong protein-DNA cross linkers that inhibit DNA replication and macromolecule synthesis. They are highly reactive molecules capable of inducing deleterious effects on both the cellular and whole organism levels and their oxidation to less harmful carboxylic acid is catalyzed by aldehyde 
dehydrogenases (ALDHs) [62]. ALDHs are universally elevated by stress to protect against oxidative damage and, in humans, one mutation in an aldh gene is correlated with high prevalence of infection [63]. In shrimp, apart from its role in the detoxification process, the ALDH may have played a role as a cellular protector during host resistance to WSSV infection [64]. Moreover, ALDH was able to decrease WSSV replication at high temperature [64]. However, the precise function of ALDH in WSSV infection remains poorly understood. In oysters, distinct gene expression level of aldh has been argued as a putative cause for differences between oysters selected for resistance or susceptibility to summer mortality, a phenomenon in which OsHV-1 was likely involved [19].

\section{Targeted signaling pathways}

Low density lipoprotein receptor-related protein 6 (LRP6; spot \#9) that belongs to the Wnt signaling pathway was down-accumulated in challenged oysters compared to controls. In humans, the Wnt signaling pathway is essential for cytomegalovirus replication, and small molecules, such as antibiotics, can interfere with LRP6 protein expression and inhibit cytomegalovirus replication [65]. Therefore, the use of antibiotics might reduce mortality of oysters exposed to OsHV-1.

The sarcoplasmic calcium binding protein (SCP; spot \#6) was down-accumulated in infected oysters. SCP is an acidic cytosolic protein with calcium binding sites that function as a calcium buffer [66]. Intracellular $\mathrm{Ca}^{2+}$ concentration is critical in the viral life cycle (capsid transport) and influences many host cell defense responses such as apoptosis $[67,68]$. The down-expression of the gene scp was already observed in post-larvae of the shrimp Penaeus modon infected with WSSV [69], and was revealed by 2-DE proteomic study in the stomachs of the shrimp Penaeus vannamei challenged with WSSV [17, 70]. Interestingly, the genome of OsHV-1 contains one ORF which encodes a cellular chloride ion channel (ORF 57) [71] that would allow the virus to modulate the host $\mathrm{Ca}^{2+}$ homeostasis. Based on its role in ion 
regulation, it is likely that salinity would modulate OsHV-1 infection.

The Steroidogenic acute regulatory protein 5 (StAR; spot \#12) was down-accumulated in challenged animals. Given that StAR is responsible for steroid biosynthesis [72], it is likely that steroid metabolism was dysregulated in infected oysters. This result is reinforced by the down-expression of heat-shock protein HSP90 1 (spot \#9) that we obtained in infected oysters. Indeed, HSP90 $\alpha 1$ is a transcriptional factor that can interact with the cytoskeleton and is involved in signal transduction from a steroid hormone receptor [73]. Steroid hormones are involved in reproduction, inflammation, immune function, and water and salt balance [74].

\section{Evidence for a Warburg effect during infection with OsHV-1}

\section{Increased glycolysis and lypolysis}

Compared to control oysters, challenged oysters showed a higher level of Triose phosphate isomerase (TPI; spot \#15) a key glycolytic enzyme, and lower levels of Malate dehydrogenase (MDH; spot \#2) and fructose 1,6-biphosphatase (Fru,-1,6-Pase; spot \#2), two key enzymes involved in gluconeogenesis. These results suggest that OsHV-1 stimulated enhanced glycolysis in oysters. Similarly, shrimps infected with white spot syndrome virus (WSSV) show an increase in accumulated protein levels in key glycolytic enzymes [17] and in their enzymatic activities [75]. Enhanced glycolysis is known to occur during viral infection in vertebrates, resulting from modulation of cellular signalling and stress responses in the host [76]. Taken together, these results agree well with the fact that carbohydrate level in oysters decrease dramatically during OsHV-1 infection $[2,3,77]$.

Challenged oysters also showed a higher level of the pancreatic triacylglycerol lipase (TL; spot \#18), an enzyme involved in the first step of fat hydrolysis and digestion. Its overaccumulation likely reflects an enhancement of lipolysis during OsHV-1 infection. In support 
of this result, several studies report that triglycerides levels decrease markedly during OsHV1 infection in C. gigas $[2,3,77,78]$. Similarly, initial stages of WSSV infection were characterized by a decrease in triglycerides content in shrimp [75].

Concomitantly, the Fatty-acid binding protein (FABPs; spot \#4), an enzyme involved in fatty acid trafficking $[79,80]$, was down-accumulated in challenged oysters compared to controls. Interestingly, the mRNA level for fabp was significantly higher in oysters selected for resistance to summer mortalities, a phenomenon in which OsHV-1 was presumably involved, compared to susceptible oysters [18]. Taken together, our results suggest that OsHV-1 infection enhanced the first step of lipolysis but fatty acid trafficking and consequently $\beta$ oxidation remained unchanged. Therefore, lipids would not only be used for energy production of the host, but also for the synthesis of macromolecules that are used in virus assembly, as previously reported in human cytomegalovirus infections [81, 82].

\section{The pore-forming $\mathrm{VDAC}$}

The Voltage-dependent anion channel (VDAC; spot \#23), a class of porin ion channel located on the outer mitochondrial membrane, plays an important role in mitochondrial membrane permeabilization (MMP) and can lead to cellular apoptosis and death [83, 84]. VDAC was over-accumulated in challenged oysters compared to controls. Several pathogens regulate MMP in their host cells to benefit their replication cycle, while in other cases, the host can use the same mechanism to combat pathogenesis [85]. In shrimp, over-accumulation of VDAC facilitates infection with WSSV whereas when the expression of VDAC was silenced, infection was delayed [17, 69, 75, 86]. Similarly in flounder Paralichthys olivaceus, vdac mRNA was upregulated in response to virus infection [69].

\section{The Warburg effect}

The increased glycolysis and VDAC accumulation in challenged oysters resemble the 
induction of a Warburg effect, which has been discovered in cancer cells [87-89]. The Warburg effect is an abnormal increase in aerobic glycolysis related to the modulation of mitochondrial metabolism. Chen et al. [75] showed that at the early stage of WSSV infection, shrimp exhibited a Warburg-like effect (i.e. an abnormal glycolysis response for generating energy and metabolic precursors), whereas at the late stage of infection, shrimp showed increased MMP and oxidative stress [69]. Accordingly, they proposed that VDAC plays different roles at different stages of WSSV infection, i.e., induction of mitochondrial changes for production of energy and metabolic precursors for viral biogenesis at the early stage but enhanced MMP and apoptosis at the late stage [69]. In our study, the Warburg effect would favour OsHV-1 by providing cellular energy and building blocks during viral genome replication.

\section{CONCLUSION}

In the present paper, we have used a 2-DE proteomic approach to identify metabolic pathways involved in OsHV-1 infection in oyster $C$. gigas. Challenged oysters showed a marked differential regulation of proteins involved in cytoskeleton organization, in protein turnover, in induction of stress signals, in signalling pathways and in energy metabolism. Interestingly, challenged oysters exhibited an aerobic glycolysis and VDAC accumulation, similar to the "Warburg effect" initially reported in cancer cells and more recently in shrimp infected with WSSV. Currently, anti-viral measures are under investigation to prevent WSSV infection and subsequent mortalities in shrimp. It was shown that hyperthermic conditions influenced the host metabolism and totally suppressed the WSSV replication [64]. Also enriched diets containing high levels of carotene led to the induction of an immune-stimulating effect in WSSV-infected shrimp that were more protected against disease [90]. In oysters, ongoing 
research aims to investigate how environmental factors and farming practices could control the Warburg effect to delay or protect oysters from disease mortality risk.

\section{Acknowledgments}

This work was supported by Ifremer (project 'Surmortalité' 2010-11 coordinated by Nathalie Cochennec-Laureau) and is part of the GIGASSAT project funded by ANRAGROBIOSPHERE No. ANR-12-AGRO-0001-01. David Tamayo was supported by the grant "Programa Posdoctoral de Perfeccionamiento de doctores del Gobierno Vasco". We thank Marie-Josée Garet-Delmas for production of inocula and Julien Normand for experimental infection. We thank Mélanie Lagarrigue, Emmanuelle Com and Charles Pineault from the Proteomics Core Facility Biogenouest, Inserm U1085, Rennes, France. We also thank PRIDE and ProteomeXchange for the dissemination of our data. We are grateful to Emma Timmins-Schiffman for revising the English version of this manuscript.

\section{Supplementary data}

The mass spectrometry proteomics data have been deposited to the ProteomeXchange Consortium (http://www.proteomexchange.org) via the PRIDE partner repository [91] with the dataset identifier PXD000905 and DOI 10.6019/PXD000905, with reviewer access (Username: reviewer42569@ebi.ac.uk, password: cpsNFcDQ, to access the data please visit: http://tinyurl.com/layze71). 


\section{FIGURE LEGENDS}

Figure 1: Box-plot of herpesvirus OsHV-1 $\mu$ Var in oysters Crassostrea gigas injected either with high-load inoculum (high OsHV-1, challenged oysters) or low-load inoculum (low OsHV-1, control oysters). Data are presented for each tank (number in x axis) at 2 days and 6 days post-injection (dpi). Data are expressed as number of viral DNA copy per ng of total DNA. Red lines within each box represent mean values ( $\mathrm{n}=10$ individuals per tank). $F$ and $\mathrm{p}$ values refer to one-way nested ANOVAs conducted separately at 2 dpi and at 6 dpi to determine differences in the quantity of OsHV-1 DNA detected in oyster tissues as a function of injection load of OsHV-1 and tank. Stars indicate significant differences among tanks within injection load.

Figure 2: Gels of a 2-DE protein profile of oyster Crassostrea gigas injected either with highload inoculum (challenged oysters, A) or low-load inoculum (control oysters, B). Results were obtained by separating $500 \mu \mathrm{g}$ of protein samples on a $11 \mathrm{~cm} \mathrm{pH} \mathrm{3-10} \mathrm{strip} \mathrm{followed} \mathrm{by}$ SDS-PAGE. The gels were stained by Coomassie blue coloration. Mr: molecular marker.

Figure 3: Reference image showing a gel of of a 2-DE protein profile oyster Crassostrea gigas injected with high-load inoculum (challenged oysters). Resolved spots are marked with corresponding spot number and excised spots were encircled in bold. The name of the protein identified is shown in Table 2 and 3 and details of the corresponding mass spectrometric data are given in the supplementary data. Mr: molecular marker. 


\section{REFERENCES}

[1] EFSA. Scientific Opinion of the Panel on Animal Health and Welfare on a request from the European Commission on the increased mortality events in Pacific oysters Crassostrea gigas. EFSA. 2010;8:1894-953.

[2] Pernet F, Barret J, Gall PL, Corporeau C, Dégremont L, Lagarde F, et al. Mass mortalities of Pacific oysters Crassostrea gigas reflect infectious diseases and vary with farming practises in the Thau lagoon. Aquaculture Environment Interactions. 2012;2:215-37.

[3] Pernet F, Lagarde F, Jeannée N, Daigle G, Barret J, Le Gall P, et al. Spatial and Temporal Dynamics of Mass Mortalities in Oysters Is Influenced by Energetic Reserves and Food Quality. PLoS ONE. 2014;9:e88469.

[4] Petton B, Pernet F, Robert R, Boudry P. Temperature influence on pathogen transmission and subsequent mortalities in juvenile Pacific oysters Crassostrea gigas. Aquaculture Environment Interactions. 2013;3:257-73.

[5] Jolivel A. Analyse statistique des données de mortalité d'huîtres acquises par l'Observatoire National Conchylicole (RESCO): Rennes 2 Agrocampus Ouest; 2012.

[6] Oden E, Martenot C, Berthaux M, Travaillé E, Malas JP, Houssin M. Quantification of ostreid herpesvirus 1 (OsHV-1) in Crassostrea gigas by real-time PCR: Determination of a viral load threshold to prevent summer mortalities. Aquaculture. 2011;317:27-31.

[7] Dégremont L, Guyader T, Tourbiez D, Pépin J-F. Is horizontal transmission of the Ostreid herpesvirus OsHV-1 in Crassostrea gigas affected by unselected or selected survival status in adults to juveniles? Aquaculture. 2013;408-409:51-7.

[8] Peeler EJ, Reese RA, Cheslett DL, Geoghegan F, Power A, Thrush MA. Investigation of mortality in Pacific oysters associated with Ostreid herpesvirus-1 $\mu$ Var in the Republic of Ireland in 2009. Preventive Veterinary Medicine. 2012;105:136-43.

[9] Paul-Pont I, Dhand NK, Whittington RJ. Influence of husbandry practices on OsHV-1 associated mortality of Pacific oysters Crassostrea gigas. Aquaculture. 2013;412-413:202-14.

[10] Jenkins C, Hick P, Gabor M, Spiers Z, Fell SA, Gu X, et al. Identification and characterisation of an ostreid herpesvirus-1 microvariant (OsHV-1 mu-var) in Crassostrea gigas (Pacific oysters) in Australia. Diseases of Aquatic Organisms. 2013;105:109-26.

[11] Bingham P, N. B, R. W, M. vA. Investigation into the first diagnosis of ostreid herpesvirus type 1 in Pacific oysters. Surveillance. 2013;40:20-4.

[12] Clegg TA, Morrissey T, Geoghegan F, Martin SW, Lyons K, Ashe S, et al. Risk factors associated with increased mortality of farmed Pacific oysters in Ireland during 2011. Preventive Veterinary Medicine. 2014;113:257-67.

[13] Segarra A, Pepin JF, Arzul I, Morga B, Faury N, Renault T. Detection and description of a particular Ostreid herpesvirus 1 genotype associated with massive mortality outbreaks of Pacific oysters, Crassostrea gigas, in France in 2008. Virus Res. 2010;153:92-9.

[14] Renault T. Analysis of clinical ostreid herpesvirus 1 (Malacoherpesviridae) specimens by sequencing amplified fragments from three virus genome areas. Journal of Virology. 2012.

[15] Schikorski D, Renault T, Saulnier D, Faury N, Moreau P, Pepin JF. Experimental infection of Pacific oyster Crassostrea gigas spat by ostreid herpesvirus 1: demonstration of oyster spat susceptibility. Vet Res. 2011;42.

[16] Schikorski D, Faury N, Pepin JF, Saulnier D, Tourbiez D, Renault T. Experimental ostreid herpesvirus 1 infection of the Pacific oyster Crassostrea gigas: Kinetics of virus DNA detection by q-PCR in seawater and in oyster samples. Virus Res. 2011;155:28-34. 
[17] Wang H-C, Wang H-C, Leu J-H, Kou G-H, Wang AHJ, Lo C-F. Protein expression profiling of the shrimp cellular response to white spot syndrome virus infection. Developmental \& Comparative Immunology. 2007;31:672-86.

[18] Huvet A, Herpin A, Degremont L, Labreuche Y, Samain JF, Cunningham C. The identification of genes from the oyster Crassostrea gigas that are differentially expressed in progeny exhibiting opposed susceptibility to summer mortality. Gene. 2004;343:211-20.

[19] Fleury E, Huvet A. Microarray Analysis Highlights Immune Response of Pacific Oysters as a Determinant of Resistance to Summer Mortality. Mar Biotechnol. 2012;14:203-17.

[20] Fleury E, Huvet A, Lelong C, de Lorgeril J, Boulo V, Gueguen Y, et al. Generation and analysis of a 29,745 unique Expressed Sequence Tags from the Pacific oyster (Crassostrea gigas) assembled into a publicly accessible database: the GigasDatabase. BMC Genomics. 2009;10.

[21] Fleury E, Moal J, Boulo V, Daniel J-Y, Mazurais D, Hénaut A, et al. Microarray-Based Identification of Gonad Transcripts Differentially Expressed Between Lines of Pacific Oyster Selected to Be Resistant or Susceptible to Summer Mortality. Mar Biotechnol. 2010;12:326-39.

[22] Normand J, Li R, Quillien V, Nicolas J-L, Boudry P, Pernet F, et al. Contrasted survival under field or controlled conditions displays associations between mRNA levels of candidate genes and response to OsHV -1 infection in the Pacific oyster Crassostrea gigas. Marine Genomics. in press.

[23] Renault T, Faury N, Barbosa-Solomieu V, Moreau K. Suppression substractive hybridisation (SSH) and real time PCR reveal differential gene expression in the Pacific cupped oyster, Crassostrea gigas, challenged with Ostreid herpesvirus 1. Developmental \& Comparative Immunology. 2011;35:725-35.

[24] Schmitt P, Santini A, Vergnes A, Degremont L, de Lorgeril J. Sequence polymorphism and expression variability of Crassostrea gigas immune related genes discriminate two oyster lines contrasted in term of resistance to summer mortalities. PLOS ONE. 2013;8:e75900.

[25] Jouaux A, Lafont M, Blin J-L, Houssin M, Mathieu M, Lelong C. Physiological change under OsHV-1 contamination in Pacific oyster Crassostrea gigas through massive mortality events on fields. BMC Genomics. $2013 ; 14$

[26] Suquet M, de Kermoysan G, Araya RG, Queau I, Lebrun L, Le Souchu P, et al. Anesthesia in Pacific oyster, Crassostrea gigas. Aquatic Living Resources. 2009;22:29-34.

[27] Pepin J-F, Riou A, Renault T. Rapid and sensitive detection of ostreid herpesvirus 1 in oyster samples by real-time PCR. Journal of Virological Methods. 2008;149:269-76.

[28] Le Deuff R-M, Renault T. Purification and partial genome characterization of a herpes-like virus infecting the Japanese oyster, Crassostrea gigas. Journal of General Virology. 1999;80:1317-22.

[29] Guévélou E, Huvet A, Galindo-Sanchez CE, Milan M, Quillien V, Daniel J-Y, et al. Sex-Specific Regulation of AMP-Activated Protein Kinase (AMPK) in the Pacific Oyster Crassostrea gigas 1. Biology of Reproduction. 2013 b;89.

[30] Guévélou E, Huvet A, Sussarellu R, Milan M, Guo X, Li L, et al. Regulation of a truncated isoform of AMP-activated protein kinase alpha (AMPKalpha) in response to hypoxia in the muscle of Pacific oyster Crassostrea gigas. Journal of Comparative Physiology, B. 2013 a;183:597-611.

[31] Corporeau C, Vanderplancke Gl, Boulais M, Suquet M, Quéré C, Boudry P, et al. Proteomic identification of quality factors for oocytes in the Pacific oyster Crassostrea gigas. Journal of proteomics. 2012;75:5554-63.

[32] Zhang G, Fang X, Guo X, Li L, Luo R, Xu F, et al. The oyster genome reveals stress adaptation and complexity of shell formation. Nature. 2012;490:49-54.

[33] Thiele H, Glandorf J, Hufnagel P, Korting G, Bluggel M. Managing proteomics data: from generation and data warehousing to central data repository. Journal of Proteomics \& Bioinformatics. 2008;1:485-507. 
[34] Sauvage C, Pépin JF, Lapègue S, Boudry P, Renault T. Ostreid herpes virus 1 infection in families of the Pacific oyster, Crassostrea gigas, during a summer mortality outbreak: Differences in viral DNA detection and quantification using real-time PCR. Virus Res. 2009.

[35] Petton B, Alunno-Bruscia M, Boudry P, Pernet F. Investigating risk factors associated with disease mortality of Pacific oysters Crassostrea gigas using standardized seed and controlled temperature elevation. Aquaculture Environment Interactions. in prep.

[36] Lan S, Wang H-C, Jiang H, Maou H, Liu X, Zhang X, et al. Direct interaction between alpha-actinin and hepatitis C virus NS5. FEBS Letters. 2003;554:289-94.

[37] Otey CA, Carpen O. Alpha-actinin revisited: A fresh look at an old player. Cell Motility and the Cytoskeleton. 2004;58:104-11.

[38] Gordon-Alonso M, Rocha-Perugini V, Alvarez S, Ursa A, Izquierdo-Useros N, Martinez-Picado J, et al. Actin-binding protein drebrin regulates HIV-1-triggered actin polymerization and viral infection. Journal of Biological Chemistry. 2013;288:28382-97.

[39] Radtke K, Dahner K, Sodeik B. Viral interactions with the cytoskeleton: a hitchhiker's guide to the cell. Cellular Microbiology. 2006;8:387-400.

[40] Taylor MP, Koyuncu OO, Enquist LW. Subversion of the actin cytoskeleton during viral infection. Nature Reviews: Microbiology. 2011;9:427-39.

[41] Li L, Liu X, Zhou Y, Wang J. On resistance to virus entry into host cells. Biophysical Journal. 2012;102:2230-3.

[42] Lyman MG, Enquist LW. Herpesvirus interactions with the host cytoskeleton. Journal of Virology. 2009;83:2058-66.

[43] Zhang H, Ghai P, Wu H, Wang C, Field J, Zhou G-L. Mammalian CAP1 (adenylyl Cyclase-Associated Protein 1) Regulates Cofilin Function, the Actin Cytoskeleton and Cell Adhesion. Journal of Biological Chemistry. 2013.

[44] Chen H, Bernstein BW, Bamburg JR. Regulating actin-filament dynamics in vivo. Trends in Biochemical Sciences. 2000;25:19-23.

[45] Paudel N, Sadagopan S, Balasubramanian S, Chandran B. Kaposi's Sarcoma-Associated Herpesvirus Latency-Associated Nuclear Antigen and Angiogenin Interact with Common Host Proteins, Including Annexin A2, Which Is Essential for Survival of Latently Infected Cells. Journal of Virology. 2012;86:1589-607.

[46] Hutagalung AH, Novick PJ. Role of Rab GTPases in membrane traffic and cell physiology. Physiological Reviews. 2011;91:119-49.

[47] Johns HL, Gonzalez-Lopez C, Sayers CL, Hollinshead M, Elliott G. Rab6 Dependent Post-Golgi Trafficking of HSV1 Envelope Proteins to Sites of Virus Envelopment. Traffic. 2013;15:157-78.

[48] Porat A, Sagiv Y, Elazar Z. A 56-kDa selenium-binding protein participates in intra-Golgi protein transport. Journal of Biological Chemistry. 2000;275:14457-65.

[49] Browne H, Bell S, Minson T, Wilson DW. An endoplasmic reticulum-retained herpes simplex virus glycoprotein $\mathrm{H}$ is absent from secreted virions: evidence for reenvelopment during egress. Journal of Virology. 1996;70:4311-6.

[50] Whiteley A, Bruun B, Minson T, Browne H. Effects of targeting herpes simplex virus type $1 \mathrm{gD}$ to the endoplasmic reticulum and trans-Golgi network. Journal of Virology. 1999;73:9515-20.

[51] Henaff D, Radtke K, Lippe R. Herpesviruses exploit several host compartments for envelopment. Traffic. 2012;13:1443-9. 
[52] Mettenleiter TC. Herpesvirus assembly and egress. Journal of Virology. 2002;76:1537-47.

[53] Beck R, Ravet M, Wieland FT, Cassel D. The COPI system: molecular mechanisms and function. FEBS Letters. 2009;583:2701-9.

[54] Hershko A, Ciechanover A. The ubiquitin system. Annual Review of Biochemistry. 1998;67:425-79.

[55] Boutell C, Sadis S, Everett RD. Herpes simplex virus type 1 immediate-early protein ICP0 and its isolated RING finger domain act as ubiquitin E3 ligases in vitro. Journal of Virology. 2002;76:841-50.

[56] He N, Qin Q, Xu X. Differential profile of genes expressed in hemocytes of White Spot Syndrome Virusresistant shrimp (Penaeus japonicus) by combining suppression subtractive hybridization and differential hybridization. Antiviral Research. 2005;66:39-45.

[57] Barik S. Immunophilins: for the love of proteins. Cellular and Molecular Life Sciences. 2006;63:2889-900.

[58] Watashi K, Ishii N, Hijikata M, Inoue D, Murata T, Miyanari Y, et al. Cyclophilin B is a functional regulator of hepatitis C virus RNA polymerase. Molecular Cell. 2005;19:111-22.

[59] Negrutskii B, El'skaya A. Eukaryotic translation elongation-factor 1-alpha, structure, expression, functions and possible role in aminoacyl-tRNA channeling. Progress in Nucleic Acid Research and Molecular Biology. 1998;60:47-78.

[60] Gourlay CW, Carpp LN, Timpson P, Winder SJ, Ayscough KR. A role for the actin cytoskeleton in cell death and aging in yeast. Journal of Cell Biology. 2004;164:803-9.

[61] Lee C-K, Han JS, Won K-J, Jung S-H, Park H-J, Lee HM, et al. Diminished expression of dihydropteridine reductase is a potent biomarker for hypertensive vessels. Proteomics. 2009;9:4851-8.

[62] Vasiliou V, Pappa A, Petersen DR. Role of aldehyde dehydrogenases in endogenous and xenobiotic metabolism. Chemico-Biological Interactions. 2000;129:1-19.

[63] Lin YP, Cheng TJ. Why can't Chinese Han drink alcohol? Hepatitis B virus infection and the evolution of acetaldehyde dehydrogenase deficiency. Medical Hypotheses. 2002;59:204-7.

[64] Lin Y-R, Hung H-C, Leu J-H, Wang H-C, Kou G-H, Lo C-F. The role of aldehyde dehydrogenase and HSP70 in suppression of white spot syndrome virus replication at high temperature. Journal of Virology. 2011;85:3517-25.

[65] Kapoor A, He R, Venkatadri R, Forman M, Arav-Boger R. Wnt Modulating Agents Inhibit Human Cytomegalovirus Replication. Antimicrobial Agents \& Chemotherapy. 2013;57:2761-7.

[66] Cox JA. Calcium vector protein and sarcoplasmic calcium binding proteins from invertebrate muscle. Stimulus Response Coupling: The Role of Intracellular Calcium-Binding Proteins, ed JR Ded man, VL S mith. 1990:83-107.

[67] Cheshenko N, Del Rosario B, Woda C, Marcellino D, Satlin LM, Herold BC. Herpes simplex virus triggers activation of calcium-signaling pathways. Journal of Cell Biology. 2003;163:283-93.

[68] Mattson MP, Chan SL. Calcium orchestrates apoptosis. Nature Cell Biology. 2003;5:1041-3.

[69] Leu J-H, Lin S-J, Huang J-Y, Chen T-C, Lo C-F. A model for apoptotic interaction between white spot syndrome virus and shrimp. Fish \& Shellfish Immunology. 2013;34:1011-7.

[70] Biradar V, Narwade S, Paingankar M, Deobagkar D. White Spot Syndrome Virus infection in Penaeus monodon is facilitated by housekeeping molecules. Journal of Bioscience. 2013;38:917-24.

[71] Davison A, Trus B, Cheng N, Steven A, Watson M, Cunningham C, et al. A novel class of herpesvirus with bivalve hosts. J Gen Virol. 2005;86:41-53. 
[72] Stocco DM, Clark BJ. The role of the steroidogenic acute regulatory protein in steroidogenesis. Steroids. 1997;62:29-36.

[73] Sanchez ER. Chaperoning steroidal physiology: Lessons from mouse genetic models of Hsp90 and its cochaperones. Biochimica et Biophysica Acta - Molecular Cell Research. 2012;1823:722-9.

[74] Bahat A, Perlberg S, Melamed-Book N, Lauria I, Langer T, Orly J. StAR Enhances Transcription of Genes Encoding the Mitochondrial Proteases Involved in its Own Degradation. Molecular Endocrinology. 2014;28:208-24.

[75] Chen I-T, Aoki T, Huang Y-T, Hirono I, Chen T-C, Huang J-Y, et al. White Spot Syndrome Virus Induces Metabolic Changes Resembling the Warburg Effect in Shrimp Hemocytes in the Early Stage of Infection. Journal of Virology. 2011;85:12919-28.

[76] Yu Y, Clippinger AJ, Alwine JC. Viral effects on metabolism: changes in glucose and glutamine utilization during human cytomegalovirus infection. Trends in Microbiology. 2011;19:360-7.

[77] Pernet F, Barret J, Marty C, Moal J, Le Gall P, Boudry P. Environmental anomalies, energetic reserves and fatty acid modifications in oysters coincide with an exceptional mortality event. Marine Ecology-Progress Series. 2010;401:129-46.

[78] Tamayo D, Corporeau C, Petton B, Quéré C, Pernet F. Physiological changes in Pacific oyster Crassostrea gigas exposed to the herpesvirus OsHV-1 $\mu$ var. Aquaculture. 2014;432:304-10.

[79] Zimmerman AW, Veerkamp JH. New insights into the structure and function of fatty acid-binding proteins. Cellular and Molecular Life Sciences. 2002;59:1096-116.

[80] Borchers T, Spener F. Fatty acid binding proteins. Current topics in membranes. 1994:261-94.

[81] Lerat H, Kammoun HL, Hainault I, Mérour E, Higgs MR, Callens C, et al. Hepatitis C virus proteins induce lipogenesis and defective triglyceride secretion in transgenic mice. Journal of Biological Chemistry. 2009;284:33466-74.

[82] Diamond DL, Syder AJ, Jacobs JM, Sorensen CM, Walters K-A, Proll SC, et al. Temporal proteome and lipidome profiles reveal hepatitis $\mathrm{C}$ virus-associated reprogramming of hepatocellular metabolism and bioenergetics. PLoS Pathogens. 2010;6:e1000719.

[83] Blachly-Dyson E, Forte M. VDAC channels. IUBMB life. 2001;52:113-8.

[84] Colombini M. VDAC: The channel at the interface between mitochondria and the cytosol. Mol Cell Biochem. 2004;256-257:107-15.

[85] Boya P, Pauleau A-L, Poncet D, Gonzalez-Polo R-A, Zamzami N, Kroemer G. Viral proteins targeting mitochondria: controlling cell death. Biochimica et Biophysica Acta - Bioenergetics. 2004;1659:178-89.

[86] Wang H-CKC, Kondo H, Hirono I, Aoki T. The Marsupenaeus japonicus voltage-dependent anion channel (MjVDAC) protein is involved in white spot syndrome virus (WSSV) pathogenesis. Fish \& Shellfish Immunology. 2010;29:94-103.

[87] Maldonado EN, Lemasters JJ. Warburg Revisited: Regulation of Mitochondrial Metabolism by VoltageDependent Anion Channels in Cancer Cells. Journal of Pharmacology and Experimental Therapeutics. 2012;342:637-41.

[88] Warburg O, Posener K, Negelein E. The metabolism of cancer cells. Biochem Z. 1924;152:319-44.

[89] Warburg O. On the origin of cancer cells. Science. 1956;123:309-14.

[90] Medina-Felix D, Lopez-Elias JA, Martinez-Cordova LR, Lopez-Torres MA, Hernandez-Lopez J, RivasVega ME, et al. Evaluation of the productive and physiological responses of Litopenaeus vannamei infected with WSSV and fed diets enriched with Dunaliella sp. Journal of Invertebrate Pathology. 2014;117:9-12. 
[91] Vizcaíno JA, Côté RG, Csordas A, Dianes JA, Fabregat A, Foster JM, et al. The PRoteomics IDEntifications (PRIDE) database and associated tools: status in 2013. Nucleic Acids Research. 2013;41:D10639. 
Figure 1.

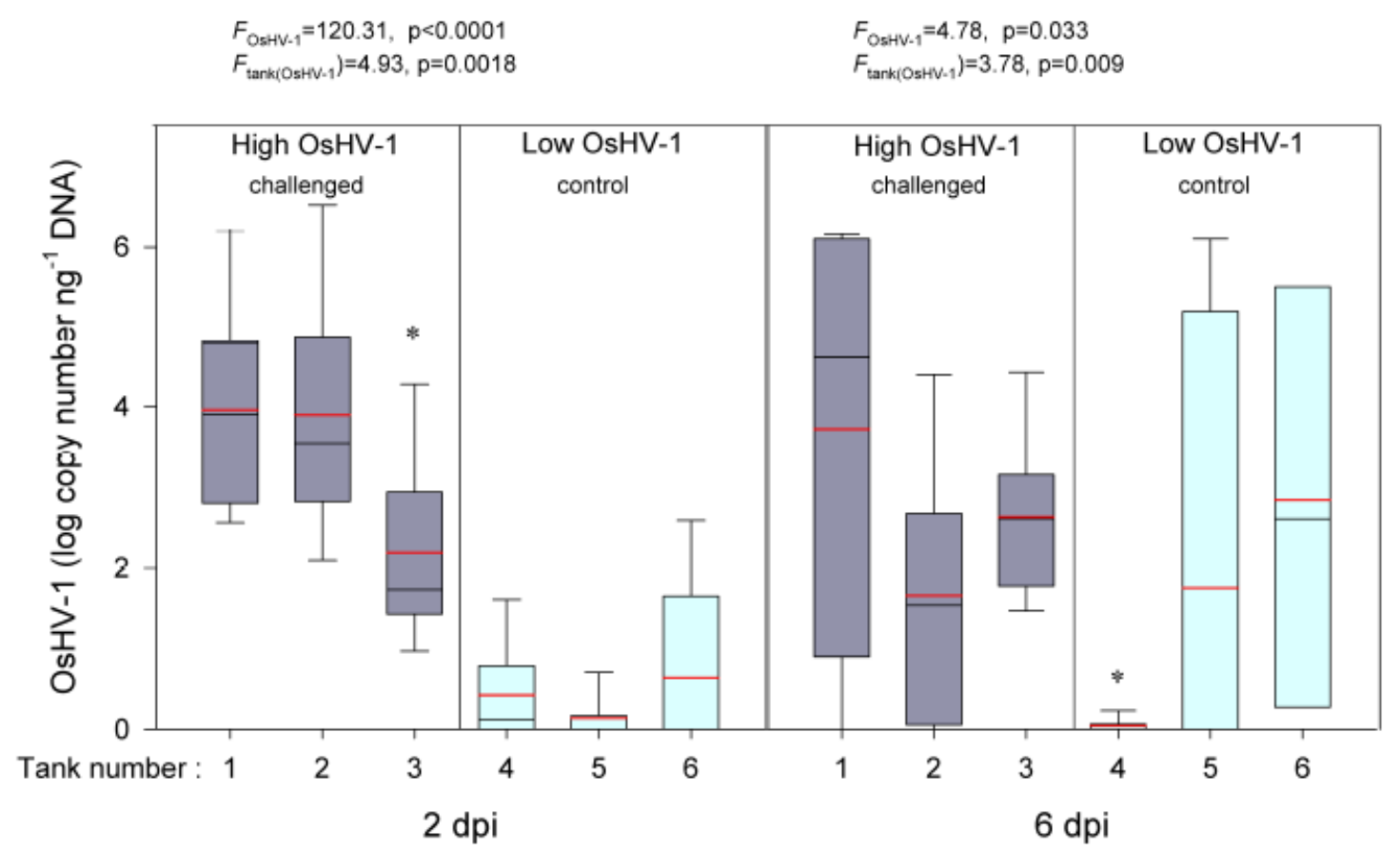


Figure 2

A) High-load (challenged oysters)

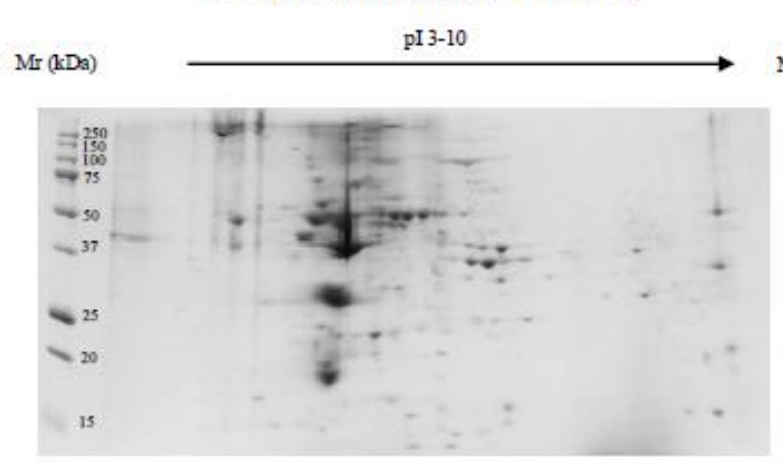

B) Low-load (control oysters)

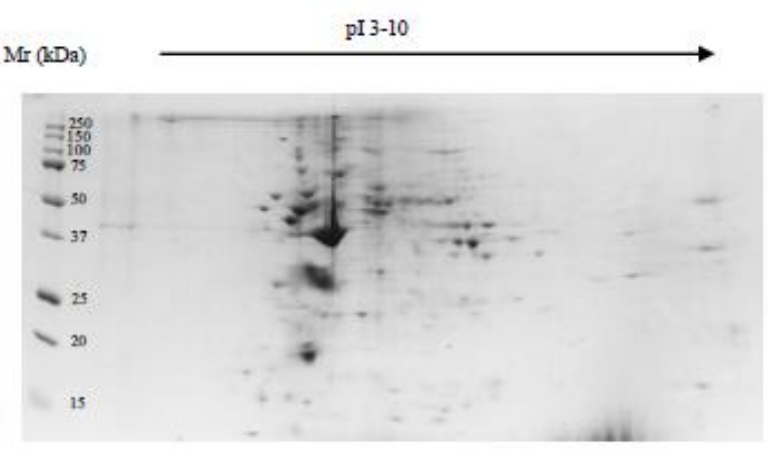


Figure 3

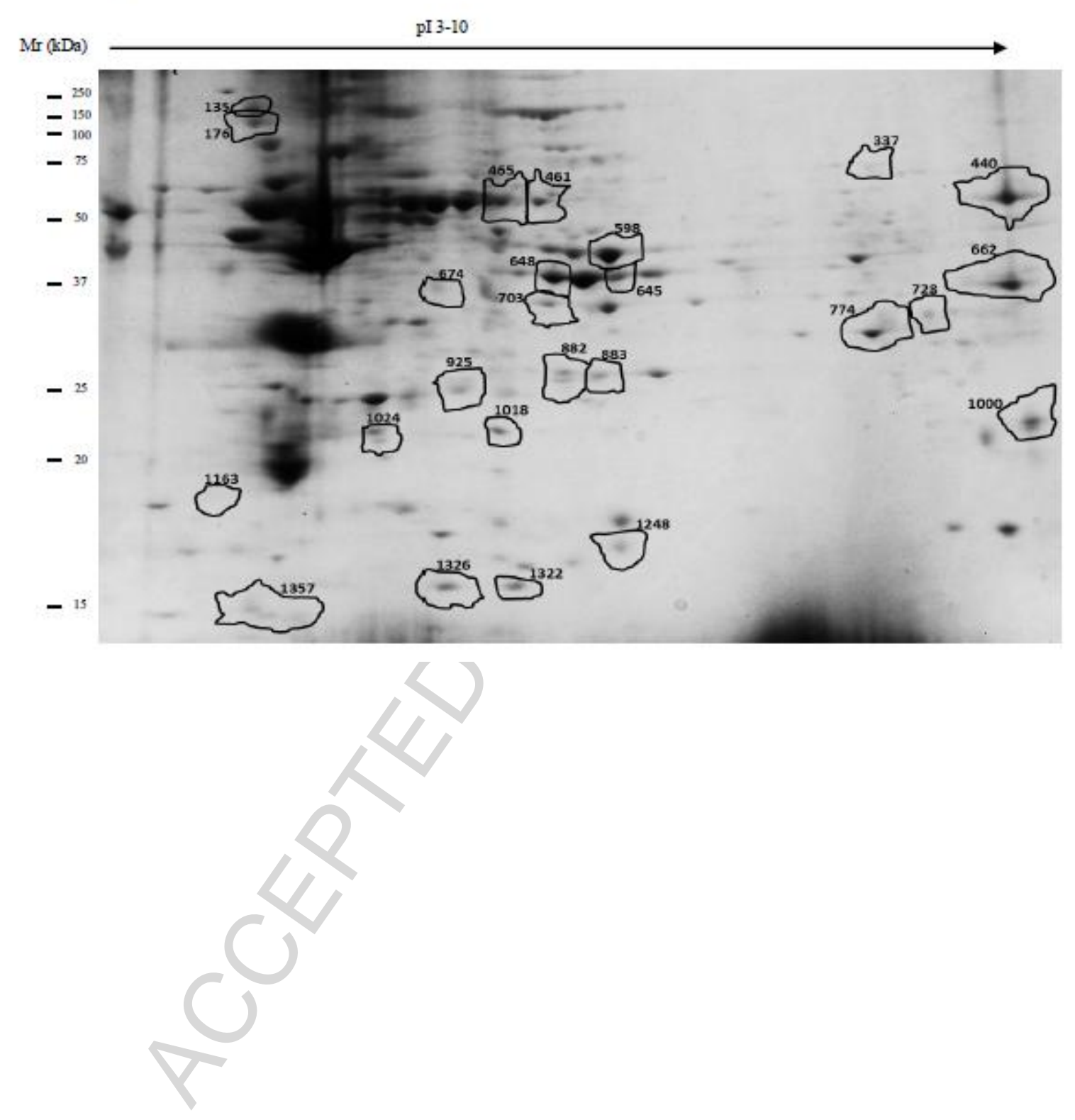


Table 1. Quantity of OsHV-1 $\mu$ Var DNA in 10 oysters chosen at 2 days post-injection for proteomic analysis expressed as copy number per ng of total DNA. Oysters were injected with high-load inoculum (high OsHV-1, challenged oysters) or with low-load inoculum (low OsHV-1, control oysters). The tanks where oysters were chosen are indicated.

\begin{tabular}{|c|c|c|c|}
\hline Treatment & Individual No & Tank & $\begin{array}{l}\text { OsHV-1 } \mu \text { Var } \\
\text { (copy number } n^{-1} \\
\text { DNA) }\end{array}$ \\
\hline \multirow{7}{*}{$\begin{array}{l}\text { High OsHV- } \\
1 \\
\text { (challenged) }\end{array}$} & 34 & 1 & $2.18 \cdot 10^{6}$ \\
\hline & 37 & 1 & $9.19 \cdot 10^{4}$ \\
\hline & 38 & 1 & $5.45 \cdot 10^{4}$ \\
\hline & 42 & 2 & $3.80 \cdot 10^{6}$ \\
\hline & 45 & 2 & $9.31 \cdot 10^{5}$ \\
\hline & Mean & & $1.41 \cdot 10^{6}$ \\
\hline & $\begin{array}{l}\text { Standard } \\
\text { deviation }\end{array}$ & & $1.59 \cdot 10^{6}$ \\
\hline \multirow{7}{*}{$\begin{array}{l}\text { Low OsHV- } \\
1 \\
\text { (control) }\end{array}$} & 61 & 4 & 0.00 \\
\hline & 63 & 4 & 0.00 \\
\hline & 67 & 4 & 4.44 \\
\hline & 73 & 5 & 0.00 \\
\hline & 79 & 5 & 0.00 \\
\hline & Mean & & 0.88 \\
\hline & $\begin{array}{l}\text { Standard } \\
\text { deviation }\end{array}$ & & 1.99 \\
\hline
\end{tabular}


Table 2. Down-accumulated proteins in challenged oyster Crassostrea gigas injected with high-load inoculum at 2 days post-injection.

\begin{tabular}{|c|c|c|c|c|c|c|c|c|c|}
\hline $\begin{array}{c}\text { serial } \\
\text { numbe } \\
r\end{array}$ & \begin{tabular}{|c} 
spot \\
numb \\
er
\end{tabular} & $\begin{array}{c}\text { average } \\
\text { fold } \\
\text { change }\end{array}$ & \begin{tabular}{|c|} 
protein \\
annotatio \\
$n$
\end{tabular} & $\begin{array}{l}\text { Uniprot } \\
\text { accession } \\
\text { number }\end{array}$ & $\begin{array}{l}\mathrm{Mr}(\mathrm{kDa}) / \mathrm{pl} \\
\text { experimental }\end{array}$ & $\begin{array}{c}\mathrm{Mr}(\mathrm{kDa}) / \mathrm{pl} \\
\text { theoritical }\end{array}$ & $\begin{array}{c}\text { Sequence } \\
\text { coverage } \\
(\%)\end{array}$ & $\begin{array}{c}\text { unique } \\
\text { peptide } \\
\text { matched }\end{array}$ & $\begin{array}{c}\text { scor } \\
\text { e }\end{array}$ \\
\hline 1 & $\begin{array}{c}337 \\
\text { CA61 }\end{array}$ & 1.3 & $\begin{array}{l}\text { Annexin } \\
\text { Adenylyl } \\
\text { cyclase- } \\
\text { associated } \\
\text { protein } \\
\text { (CAP) } \\
\text { Catalase }\end{array}$ & $\begin{array}{c}\text { K1QMV5_CRA } \\
\text { GI } \\
\text { K1QI97_CRAG } \\
\text { I } \\
\text { K1PNZ5_CRA } \\
\text { GI }\end{array}$ & $\begin{array}{l}75 / 9.2 \\
75 / 9.2\end{array}$ & $\begin{array}{l}29.9 / 5.60 \\
67.3 / 5.83 \\
58.0 / 9.05\end{array}$ & $\begin{array}{l}8.4 \\
3.9\end{array}$ & $\begin{array}{l}5 \\
2\end{array}$ & $\begin{array}{c}465 . \\
35 \\
\\
229 . \\
04 \\
87.9 \\
7\end{array}$ \\
\hline 2 & $\begin{array}{c}674 \\
\text { CA61 }\end{array}$ & 1.4 & \begin{tabular}{|c|} 
Malate \\
dehydrogen \\
ase \\
Glycerol-3- \\
phosphate \\
dehydrogen \\
ase (GPDH) \\
Fructose- \\
$1,6-$ \\
biphosphata \\
se (Fru,-1,6- \\
Pase) \\
Ubiquitin \\
fusion \\
degradation \\
protein \\
(UFD) \\
\end{tabular} & $\begin{array}{c}\text { K1PU26_CRA } \\
\text { GI } \\
\text { K1P8T5_CRAG } \\
\text { K1QSB0_CRA } \\
\text { GI } \\
\text { K1QUK1_CRA } \\
\text { GI }\end{array}$ & $35 / 7$ & $\begin{array}{l}36.3 \text { / } 6.15 \\
38.8 \text { / } 5.81 \\
36.8 \text { / } 6.28 \\
78 \text { / } 9.14\end{array}$ & 11.7 & 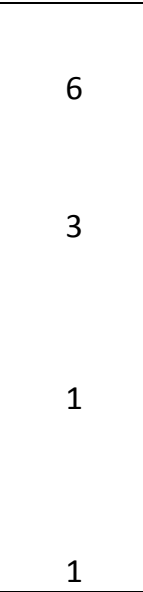 & $\begin{array}{c}337 . \\
80 \\
139 . \\
57 \\
\\
58.9 \\
9 \\
\\
50.0 \\
6\end{array}$ \\
\hline 3 & $\begin{array}{l}1326 \\
\text { CA61 }\end{array}$ & 1.3 & $\begin{array}{c}\text { Dynein } \\
\text { heavy chain } \\
10 \\
\text { (fragment) }\end{array}$ & $\begin{array}{c}\text { K1R5R4_CRA } \\
\text { GI }\end{array}$ & $35 / 7$ & $585.1 / 5.57$ & 0.8 & 4 & $\begin{array}{c}204 . \\
62\end{array}$ \\
\hline 4 & $\begin{array}{l}1357 \\
\text { CA61 }\end{array}$ & 1.3 & \begin{tabular}{|c|} 
Fatty acid \\
binding \\
protein, \\
adipocyte \\
(FABP) \\
Fatty acid \\
binding \\
protein, \\
brain (FABP) \\
Actin \\
\end{tabular} & $\begin{array}{c}\text { K1P2H1_CRA } \\
\text { GI } \\
\text { K1QPM9_CRA } \\
\text { GI } \\
\text { K1QPJ1_CRAG } \\
\text { I }\end{array}$ & $\begin{array}{l}15 / 5.2 \\
15 / 5.2\end{array}$ & $\begin{array}{l}14.3 / 4.88 \\
15.3 / 4.86 \\
41.6 / 5.38\end{array}$ & $\begin{array}{l}31.4 \\
5.6\end{array}$ & $\begin{array}{l}6 \\
2\end{array}$ & $\begin{array}{c}670 . \\
62 \\
\\
340 . \\
14 \\
142 . \\
08\end{array}$ \\
\hline 5 & $\begin{array}{c}703 \\
\text { CA67 }\end{array}$ & 1.7 & \begin{tabular}{|c|} 
Glyceraldehy \\
de-3- \\
phosphate \\
dehydrogen \\
ase (GAPDH) \\
Malate \\
dehydrogen \\
ase
\end{tabular} & $\begin{array}{c}\text { K1Q350_CRA } \\
\text { GI } \\
\text { K1R4Z3_CRAG } \\
\text { I }\end{array}$ & $\begin{array}{l}35 / 7.5 \\
35 / 7.5\end{array}$ & $\begin{array}{l}36.1 / 7.68 \\
29.8 / 5.85\end{array}$ & 45.4 & 15 & $\begin{array}{c}978 . \\
48 \\
706 . \\
40\end{array}$ \\
\hline 6 & $\begin{array}{l}1163 \\
\text { CA67 }\end{array}$ & 1.5 & \begin{tabular}{|c|} 
Sarcoplasmic \\
calcium- \\
binding \\
protein (SCP) \\
Arginine \\
kinase \\
Coatomer \\
subunit zeta- \\
1
\end{tabular} & $\begin{array}{c}\text { K1PBH1_CRA } \\
\text { GI } \\
\text { K1PLF9_CRAG } \\
\text { I } \\
\text { K1Q6U0_CRA } \\
\text { GI }\end{array}$ & $\begin{array}{l}17 / 4.8 \\
17 / 4.8\end{array}$ & $\begin{array}{l}20.7 / 4.52 \\
39.6 / 6.65 \\
20.9 / 4.67\end{array}$ & $\begin{array}{l}30.7 \\
8.6\end{array}$ & 4 & $\begin{array}{c}295 . \\
40 \\
159 . \\
74 \\
49.0 \\
8\end{array}$ \\
\hline
\end{tabular}




\begin{tabular}{|c|c|c|c|c|c|c|c|c|c|}
\hline 7 & $\begin{array}{c}461 \\
\text { CA73 }\end{array}$ & 1.3 & $\begin{array}{c}\text { ATP } \\
\text { synthase } \alpha\end{array}$ & $\begin{array}{c}\text { K1R6Z7_CRAG } \\
\text { I }\end{array}$ & $50 / 7.5$ & $59.8 / 9.12$ & 38.9 & 22 & \begin{tabular}{|l|}
134 \\
0.26 \\
\end{tabular} \\
\hline 8 & $\begin{array}{c}135 \mathrm{CA} \\
79\end{array}$ & 1.5 & \begin{tabular}{|c|} 
Endoplasmin \\
$\alpha$-actinin \\
\end{tabular} & $\begin{array}{c}\text { K1QX26_CRA } \\
\text { GI } \\
\text { K1RH58_CRA } \\
\text { GI }\end{array}$ & $\begin{array}{l}100 / 5 \\
100 / 5\end{array}$ & $\begin{array}{l}125.4 / 4.73 \\
102.1 / 5.19\end{array}$ & $\begin{array}{l}20.1 \\
4.7 \\
\end{array}$ & 22 & \begin{tabular}{|c|}
158 \\
0.62 \\
175. \\
12 \\
\end{tabular} \\
\hline 9 & $\begin{array}{c}176 \\
\text { CA79 }\end{array}$ & 1.3 & $\begin{array}{c}\text { Heat shock } \\
\text { protein } \\
90 \alpha 1 \\
\text { (HSP90 } 1 \text { 1) } \\
\text { Low density } \\
\text { lipoprotein } \\
\text { receptor- } \\
\text { related } \\
\text { protein 6 } \\
\text { (LRP6) } \\
\text { Actin 2 } \\
\text { Drebrin }\end{array}$ & \begin{tabular}{|c|} 
K1PNQ5_CRA \\
GI \\
\\
K1QY50_CRA \\
GI \\
Q8TA69_CRA \\
GI \\
K1R3G2_CRA \\
GI
\end{tabular} & $\begin{array}{l}90 / 5 \\
90 / 5 \\
90 / 5 \\
\end{array}$ & $\begin{array}{l}74.8 / 4.79 \\
41.7 / 5.19 \\
59.7 / 4.85\end{array}$ & $\begin{array}{r}14.2 \\
13.3 \\
8.3\end{array}$ & 23 & $\begin{array}{c}135 \\
1.24 \\
\\
\\
74.8 \\
0 \\
195 . \\
60 \\
153 . \\
91\end{array}$ \\
\hline 10 & $\begin{array}{c}648 \\
\text { CA79 }\end{array}$ & 1.3 & \begin{tabular}{|c|} 
Arginine \\
kinase \\
Fructose- \\
biphosphata \\
se aldolase \\
\end{tabular} & $\begin{array}{c}\text { K1PLF9_CRAG } \\
\text { I } \\
\text { K1R8R6_CRA } \\
\text { GI }\end{array}$ & $\begin{array}{l}37 / 7.5 \\
37 / 7.5\end{array}$ & $\begin{array}{l}39.6 \text { / } 6.65 \\
43.5 / 5.83 \\
\end{array}$ & 12.3 & 20 & \begin{tabular}{|c|}
136 \\
2.16 \\
264. \\
90 \\
\end{tabular} \\
\hline 11 & $\begin{array}{c}882 \\
\text { CA79 }\end{array}$ & 1.2 & \begin{tabular}{|c|} 
Uncharacteri \\
zed protein \\
Glutathione- \\
S- \\
transferase \\
A \\
\end{tabular} & $\begin{array}{c}\text { K1P1Q0_CRA } \\
\text { GI } \\
\text { K1R6D4_CRA } \\
\text { GI }\end{array}$ & $\begin{array}{l}25 / 7.5 \\
25 / 7.5 \\
\end{array}$ & $\begin{array}{l}17.9 / 9.12 \\
26.5 / 6.26 \\
\end{array}$ & 10.0 & 2 & $\begin{array}{c}138 . \\
52 \\
125 . \\
30 \\
\end{array}$ \\
\hline 12 & $\begin{array}{l}925 \\
\text { CA79 }\end{array}$ & 1.2 & \begin{tabular}{|c|} 
Cyclophilin B \\
Dihydropteri \\
dine \\
reductase \\
(DHPR) \\
Steroidogeni \\
c acute \\
regulatory \\
protein 5 \\
(StAR) \\
Non- \\
selenium \\
glutathione \\
peroxidase \\
\end{tabular} & $\begin{array}{c}\text { K1Q5P7_CRA } \\
\text { GI } \\
\text { K1PFL3_CRAG } \\
\text { K1PIK9_CRAGI } \\
\text { A7M7T7_CRA } \\
\text { GI }\end{array}$ & $\begin{array}{l}25 / 7 \\
25 / 7\end{array}$ & $\begin{array}{l}28.2 / 5.36 \\
24.4 / 6.40\end{array}$ & 12.7 & 3 & $\begin{array}{c}312 . \\
12 \\
152 . \\
17 \\
\\
50.2 \\
5 \\
44.1 \\
1 \\
\end{array}$ \\
\hline 13 & $\begin{array}{l}1322 \\
\text { CA79 }\end{array}$ & 1.2 & $\begin{array}{l}\text { Uncharacteri } \\
\text { zed protein }\end{array}$ & $\begin{array}{c}\text { K1RNZ4_CRA } \\
\text { GI }\end{array}$ & $25 / 7.2$ & 34.1 / 9.94 & 3.3 & 1 & $\begin{array}{c}36.1 \\
9\end{array}$ \\
\hline
\end{tabular}


Table 3. Up-accumulated proteins in challenged oyster Crassostrea gigas injected with highload inoculum at 2 days post-injection.

\begin{tabular}{|c|c|c|c|c|c|c|c|c|c|}
\hline $\begin{array}{c}\text { serial } \\
\text { number }\end{array}$ & $\begin{array}{c}\text { spot } \\
\text { numbe } \\
r\end{array}$ & $\begin{array}{c}\text { average } \\
\text { fold } \\
\text { change }\end{array}$ & $\begin{array}{c}\text { protein } \\
\text { annotatio } \\
\mathbf{n}\end{array}$ & $\begin{array}{l}\text { Uniprot } \\
\text { accession } \\
\text { number }\end{array}$ & $\begin{array}{c}\mathrm{Mr} \\
(\mathrm{kDa}) / \mathrm{p} \\
\mathrm{I} \\
\text { experi } \\
\text { mental }\end{array}$ & $\begin{array}{c}\text { Mr (kDa)/pl } \\
\text { theoritical }\end{array}$ & $\begin{array}{c}\text { Sequence } \\
\text { coverage (\%) }\end{array}$ & $\begin{array}{l}\text { unique } \\
\text { peptide } \\
\text { matched }\end{array}$ & $\begin{array}{c}\text { scor } \\
\text { e }\end{array}$ \\
\hline 14 & \begin{tabular}{|c|}
645 \\
IA34
\end{tabular} & 1.5 & $\begin{array}{c}\text { Arginine } \\
\text { kinase }\end{array}$ & K1PLF9_CRAGI & $37 / 8$ & $39.6 / 6.65$ & 3.3 & 13 & $\begin{array}{c}801 . \\
95\end{array}$ \\
\hline 15 & $\begin{array}{l}883 \\
\text { IA34 }\end{array}$ & 1.3 & \begin{tabular}{|} 
Uncharacteriz \\
ed protein \\
Arginine \\
kinase \\
Triosephosph \\
ate \\
isomerase \\
ES1-like \\
protein \\
Glutathione S \\
transferase A \\
\end{tabular} & $\begin{array}{l}\text { K1QHA4_CRAG } \\
\text { K1PLF9_CRAGI } \\
\text { K1PJ59_CRAGI } \\
\text { K1RPZ2_CRAGI } \\
\text { K1QJ85_CRAGI }\end{array}$ & $\begin{array}{l}25 / 8 \\
25 / 8 \\
25 / 8 \\
25 / 8 \\
25 / 8\end{array}$ & $\begin{array}{l}35.4 \text { / } 8.68 \\
39.6 \text { / } 6.65 \\
18.7 \text { / } 5.73 \\
99.9 \text { / } 9.34 \\
23.0 \text { / } 8.80 \\
\end{array}$ & $\begin{array}{l}33.1 \\
13.1 \\
15.3 \\
1.9 \\
6.0 \\
\end{array}$ & $\begin{array}{l}2 \\
1 \\
1\end{array}$ & $\begin{array}{c}443 . \\
05 \\
267 . \\
44 \\
157 . \\
43 \\
52.2 \\
6 \\
48.9 \\
4 \\
\end{array}$ \\
\hline 16 & $\begin{array}{l}1000 \\
\text { IA34 }\end{array}$ & 1.6 & $\begin{array}{c}\text { Muscle LIM } \\
\text { protein } \\
\text { Mlp84B } \\
\text { myophilin } \\
\text { Calponin-2 } \\
\text { Cyclophilin C } \\
\end{array}$ & $\begin{array}{l}\text { K1R781_CRAGI } \\
\text { K1PFT9_CRAGI } \\
\text { K1R1X5_CRAGI } \\
\text { K1Q9Z5_CRAGI }\end{array}$ & $\begin{array}{l}20 / 10 \\
20 / 10 \\
20 / 10 \\
20 / 10\end{array}$ & $\begin{array}{l}21.2 \text { / } 9.84 \\
20.4 \text { / } 9.60 \\
43.3 / 7.02 \\
22.6 \text { / } 9.41 \\
\end{array}$ & $\begin{array}{r}50.8 \\
35.8 \\
20.2 \\
15.5 \\
\end{array}$ & $\begin{array}{l}8 \\
5 \\
6 \\
3 \\
\end{array}$ & $\begin{array}{c}458 . \\
01 \\
296 . \\
17 \\
284 . \\
94 \\
176 . \\
88 \\
\end{array}$ \\
\hline 17 & $\begin{array}{l}598 \\
\text { IA37 }\end{array}$ & 1.5 & Calponin-2 & K1R1X5_CRAGI & $45 / 8$ & $43.3 / 7.02$ & 80.8 & 41 & $\begin{array}{l}281 \\
1.29 \\
\end{array}$ \\
\hline 18 & $\begin{array}{c}662 \\
\text { IA37 }\end{array}$ & 1.2 & $\begin{array}{c}\text { Pancreatic } \\
\text { triacylglycerol } \\
\text { lipase (TL) }\end{array}$ & K1Q1K6_CRAGI & $37 / 10$ & 43.0 / 9.95 & 5.2 & 1 & $\begin{array}{c}70.3 \\
1\end{array}$ \\
\hline 19 & $\begin{array}{l}1248 \\
\text { IA37 }\end{array}$ & 1.2 & $\begin{array}{c}\text { Universal } \\
\text { stress protein } \\
\text { (Usp) }\end{array}$ & K1Q1L4_CRAGI & $15 / 8$ & $15.7 / 6.96$ & 24.6 & 3 & $\begin{array}{c}223 . \\
95\end{array}$ \\
\hline 20 & $\begin{array}{l}465 \\
\text { IA38 }\end{array}$ & 1.3 & \begin{tabular}{|c|} 
Aldehyde \\
retinal \\
dehydrogena \\
se 1a \\
(ALDH1a) \\
Aldehyde \\
retinal \\
dehydrogena \\
se 1b \\
(ALDH1b) \\
ATP synthase \\
subunit \\
alpha, \\
mitochondria \\
I \\
Aldehyde \\
dehydrogena \\
se (ALDH) \\
Selenium- \\
binding \\
protein 1 \\
(SBP1)
\end{tabular} & \begin{tabular}{|l} 
K1R266_CRAGI \\
K1QVG5_CRAG \\
K1R6Z7_CRAGI \\
K1Q9Z4_CRAGI \\
K1QI40_CRAGI
\end{tabular} & $\begin{array}{l}50 / 7.2 \\
50 / 7.2\end{array}$ & $\begin{array}{l}62.1 / 7.72 \\
53.1 / 5.69 \\
59.8 / 9.12 \\
25.3 / 5.49\end{array}$ & $\begin{array}{l}23.5 \\
14.4\end{array}$ & $\begin{array}{l}11 \\
4\end{array}$ & $\begin{array}{c}121 \\
9.55 \\
\\
774 . \\
32 \\
\\
709 . \\
24 \\
241 . \\
71 \\
58.3 \\
5\end{array}$ \\
\hline 21 & $\begin{array}{r}440 \\
\text { IA42 }\end{array}$ & 1.3 & $\begin{array}{l}\text { Elongation } \\
\text { factor } 1 \alpha\end{array}$ & K1QGS8_CRAG & $50 / 10$ & $50.4 / 9.80$ & 19.5 & 10 & $\begin{array}{c}572 . \\
27\end{array}$ \\
\hline
\end{tabular}




\begin{tabular}{|c|c|c|c|c|c|c|c|c|c|}
\hline & & & $(\mathrm{EF} 1 \alpha)$ & & & & & & \\
\hline 22 & $\begin{array}{l}728 \\
\text { IA42 }\end{array}$ & 1.2 & Calponin-2 & K1R1X5_CRAGI & 30 / 9.5 & $43.3 / 7.02$ & 18.7 & 5 & $\begin{array}{c}311 . \\
43\end{array}$ \\
\hline 23 & $\begin{array}{c}774 \\
\text { IA42 } \\
\end{array}$ & 1.2 & $\begin{array}{c}\text { Voltage- } \\
\text { dependent } \\
\text { anion } \\
\text { channel } \\
\end{array}$ & $\begin{array}{c}\text { A5LGH1_CRAG } \\
\text { I }\end{array}$ & $30 / 9.2$ & $30.3 / 8.93$ & 57.1 & 13 & $\begin{array}{c}929 . \\
47\end{array}$ \\
\hline 24 & $\begin{array}{l}1018 \\
\text { IA42 }\end{array}$ & 1.3 & \begin{tabular}{|c|}
$\begin{array}{c}\text { Protein lethal } \\
\text { (2) essential } \\
\text { for life } \\
\\
\text { Calponin-2 } \\
\text { Ras related } \\
\text { protein RAB2 }\end{array}$ \\
\end{tabular} & $\begin{array}{c}\text { K1RFF7_CRAGI } \\
\text { K1R1X5_CRAGI } \\
\text { K1QBM3_CRA } \\
\text { GI }\end{array}$ & $\begin{array}{l}20 / 7.2 \\
20 / 7.2 \\
20 / 7.2\end{array}$ & $\begin{array}{l}20.9 / 6.26 \\
43.3 / 7.02 \\
23.3 / 6.25\end{array}$ & $\begin{array}{r}36.7 \\
17.4 \\
12.8\end{array}$ & 5 & $\begin{array}{c}297 . \\
48 \\
202 . \\
46 \\
160 . \\
32\end{array}$ \\
\hline 25 & $\begin{array}{l}1024 \\
\text { IA42 }\end{array}$ & 1.3 & $\begin{array}{c}\text { Mammalian } \\
\text { ependydim- } \\
\text { related } \\
\text { protein } 1 \\
\text { Extracellular } \\
\text { Superoxide } \\
\text { dismutase } \\
\text { Cu-Zn (Ec- } \\
\text { SOD) }\end{array}$ & $\begin{array}{l}\text { K1PP20_CRAGI } \\
\text { K1QLW5_CRA } \\
\text { GI }\end{array}$ & $\begin{array}{c}30 / 6.5 \\
30 / 6.5\end{array}$ & $28.5 / 9.51$ & . & 2 & $\begin{array}{c}115 . \\
67 \\
\\
53.3 \\
2\end{array}$ \\
\hline
\end{tabular}


Graphical abstract

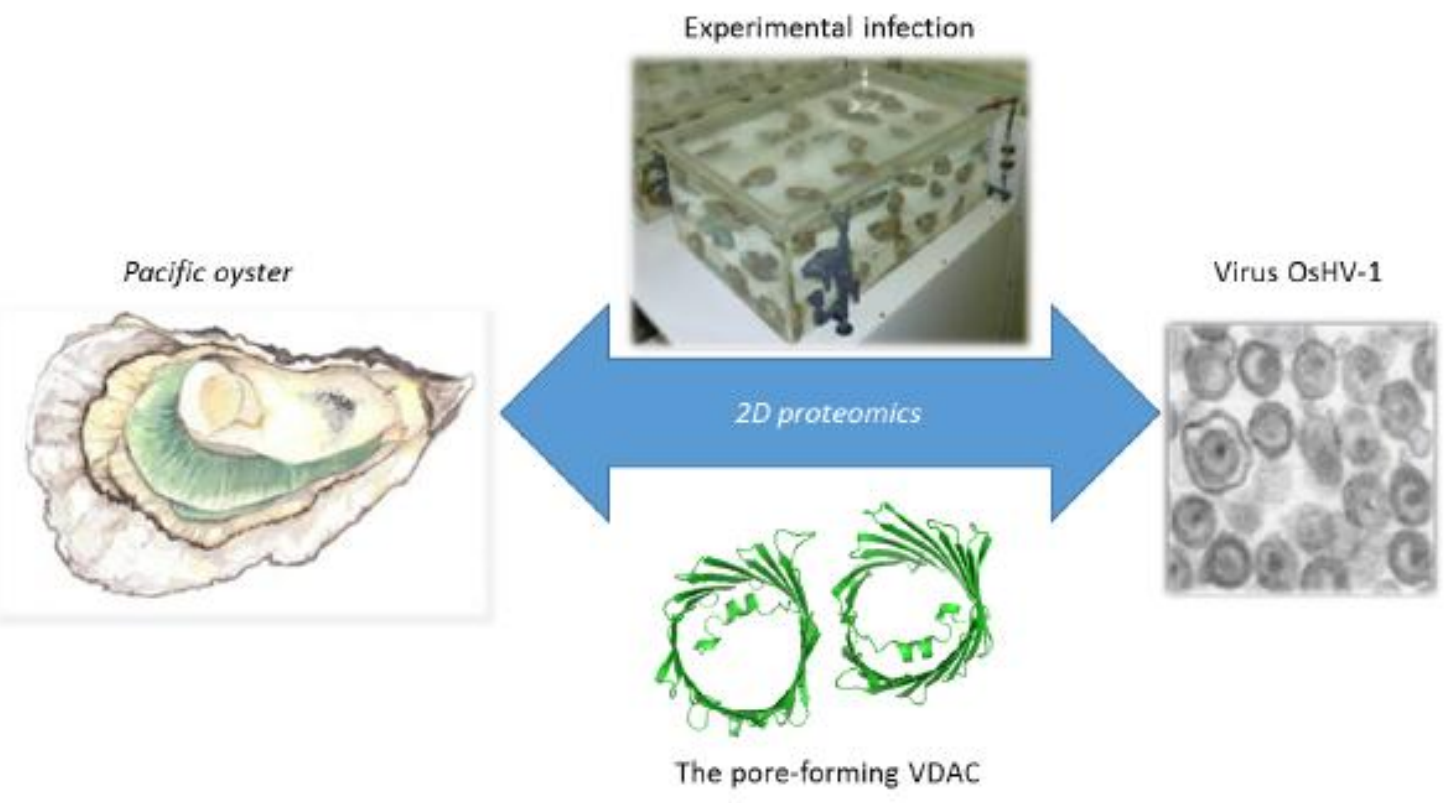

